Research Paper

\title{
HSF-1, HIF-1 and HSP90 expression on recombinant Pichia pastoris under fed-batch fermentation
}

\author{
Andrea B. Zepeda ${ }^{1,2}$, Carolina A. Figueroa ${ }^{1,2}$, Dulcineia S.P. Abdalla ${ }^{3}$, \\ Andrea Q. Maranhão ${ }^{4}$, Patricio H. Ulloa ${ }^{1}$, Adalberto Pessoa Jr. ${ }^{2}$, Jorge G. Farías ${ }^{1 *}$ \\ ${ }^{1}$ Departamento de Ingeniería Química, Facultad de Ingeniería, Ciencias y Administración, \\ Universidad de La Frontera, Temuco, Chile. \\ ${ }^{2}$ Departamento de Tecnologia Bioquímico-Farmacêutica, Faculdade de Ciências Farmacêuticas, \\ Universidade de São Paulo, São Paulo, SP, Brazil. \\ ${ }^{3}$ Departamento de Análises Clínicas e Toxicológicas, Faculdade de Ciências Farmacêuticas, \\ Universidade de São Paulo, São Paulo, SP, Brazil. \\ ${ }^{4}$ Departamento de Biología Celular, Instituto de Ciências Biológicas, Universidade de Brasília, \\ Brasília, DF, Brazil.
}

Submitted: May 28, 2013; Approved: September 09, 2013.

\begin{abstract}
Pichia pastoris is a methylotrophic yeast used as an efficient expression system for heterologous protein production as compared to other expression systems. Considering that every cell must respond to environmental changes to survive and differentiate, determination of endogenous protein related to heat stress responses and hypoxia, it would necessary to establish the temperature and methanol concentration conditions for optimal growth. The aim of this study is characterize the culture conditions through the putative biomarkers in different conditions of temperature and methanol concentration. Three yeast cultures were performed: $3 \mathrm{X}=3 \%$ methanol $-10{ }^{\circ} \mathrm{C}, 4 \mathrm{X}=3 \%$ methanol $-30{ }^{\circ} \mathrm{C}$, and $5 \mathrm{X}=1 \%$ methanol $-10^{\circ} \mathrm{C}$. The expression level of HIF- $1 \alpha$, HSF-1, HSP-70 and HSP-90 biomarkers were measured by Western blot and in situ detection was performed by immunocytochemistry. The western blot results of HIF- $1 \alpha$ and HSP-90 did not indicate statistically significant in the culture conditions studied. Respect to biomarkers location, HIF- $1 \alpha$ and HSP-90 presented differences between cultures. In conclusion, the results suggest the cultures in a hypoxic condition produce a high density and yeast cells smaller. Beside the high density would not necessary related with a high production of recombinant proteins in modified-genetically $P$. pastoris.
\end{abstract}

Key words: recombinant yeast, heat stress protein, hypoxia, chaperone.

\section{Introduction}

Pichia pastoris is a useful system for the expression of milligram-to-gram quantities of a protein, which can be scaled up to fermentation to meet greater demands. Compared with mammalian cells, $P$. pastoris not require a complex growth medium or culture conditions, they are as easy to manipulate genetically as Escherichia coli and have a eukaryotic protein-synthesis pathway (Fischer et al., 1999). The expression level of proteins in P. pastoris depends critically of many processes, including stress re- sponses to environmental factors, and protein folding/aggregation and secretion are highly interrelated. Among the environmental factors influencing protein expression and secretion, $\mathrm{pH}$, osmolarity, carbon source (Ni et al., 2008), oxygen availability and temperature appear to be particularly important (Mattanovich et al., 2004; Solà et al., 2007), which have proven to be cell type-specific and vary depending on the product that is generated (Verbelen et al., 2009), so it has not yet been achieved a specific method, as biomarkers, to determine the effects of these conditions to

Send correspondence to J.G. Farias. Departamento de Ingeniería Química, Facultad de Ingeniería, Ciencias y Administración. Universidad de La Frontera, Casilla 54-D, Temuco, Chile. E-mail: jorge.farias@ufrontera.cl. 
find the optimal parameters for each model. Among the adverse consequences due to disregard the effects of these parameters on the cultivation of yeast is the generation of a hypoxic environment (Verbelen et al., 2009) that produce a response to a reduced oxygen level through the hypoxia-inducible factor-1 (HIF-1), which one regulates the transcription of several genes involved in the adaptative response of the cell to the hypoxic conditions (Braliu et al., 2006).

HIF-1 $\alpha$ is stabilized in hypoxia and translocated to the nucleus, where it exerts its function as a transcription factor. Under certain conditions, HIF-1 $\alpha$ can also be subjected to VHL- and oxygen-independent degradation (Mabjeesh et al., 2002; Isaacs et al., 2002). This pathway is probably regulated by the molecular chaperone Hsp90, which can interact with the PAS domain of HIF-1 $\alpha$ thereby accelerating its stabilization or modulating its DNA binding activity (Gogate et al., 2012). Hypoxia-inducible factor 1 (HIF-1) is the most prominent and well-described transcription factor that activates the hypoxic expression of target genes involved in different functions such as oxygen transport, iron metabolism, glycolysis, glucose uptake, growth factor signalling and apoptosis (Semenza, 2001).

Hsp90 is among the most abundant proteins in the cytosol of eukaryotic cells (Buchner, 1999). As chaperones, Hsp90 prevents the aggregation of unfolded proteins generated by heat shock (Mayer and Bukau, 1999), oxidative (Fukuda et al., 19996) or ischemic stresses (Wagstaff et al., 1996), and prevents the degradation of the proteins (Ficker et al., 2003). For this reason, the aim of this study is to identify potential biomarkers that indicate whether the conditions of temperature and concentration of methanol generate a hypoxic environment that will affect the density of growth of $P$. pastoris recombinant in fedbatch culture.

\section{Methods}

\section{Reagents}

The solvents used were of analytical grade. The culture medium and glycerol were autoclaved at $121^{\circ} \mathrm{C}$ for 20 min at $1 \mathrm{~atm}$ and glucose at $0.5 \mathrm{~atm}$. Solutions and buffers were prepared with deionized water, besides methanol, biotin, ampicillin, casamino acids, YNB medium ("Yeast Nitrogen Base") and other reagents were sterilized by filtration on membrane of 0.22 microns.

\section{Strain}

We used lineage SMD1168 (Invitrogen (): $\Delta$ pep4::URA3 $\Delta$ kex1::SUC2his4ura3 (Cereghimo and Cregg, 2000) with His-Mut+ phenotype that was used for the expression of scFv. The genetically modified strain was provided by the research group of Professor Dr. Dulcineia Saes Parra Abdalla of the Department of Clinical and Toxicological Analysis of the de Ciências Farmacêuticas-USP and was built by the group of Prof. Dr. Andrea Maranhão of the Department of Molecular Biology of Universidade de Brasília.

\section{Maintenance and reactivation of $P$. pastoris}

For the preservation of cells of $P$. pastoris, the colonies were replicated three months on YPD solid medium (Yeast Extract Peptone Dextrose) (yeast extract 1\% (w/v), casein peptone $2 \%(\mathrm{w} / \mathrm{v})$, glucose $2 \%(\mathrm{w} / \mathrm{v})$, bacteriological agar $1.2 \%(\mathrm{w} / \mathrm{v}))$ and incubated at $30{ }^{\circ} \mathrm{C}$ for $24 \mathrm{~h}$. After that period, the colonies were removed from plates and inoculated into Erlenmeyer flasks of $500 \mathrm{~mL}$ capacity, containing $100 \mathrm{~mL}$ of YPD liquid medium at $30{ }^{\circ} \mathrm{C}$ and $250 \mathrm{rpm}$ for $24 \mathrm{~h}$. Then, the colonies were stored at $4{ }^{\circ} \mathrm{C}$ and $-70^{\circ} \mathrm{C}$ in YPD medium containing 20\% (v/v) sterile glycerol. For the reactivation step, was inoculated $1 \mathrm{~mL}$ of frozen material in Erlenmeyer flasks of $500 \mathrm{~mL}$ capacity containing $100 \mathrm{~mL}$ growth medium BMGY (Buffered Glycerol Complex Medium) (YNB medium + ammonium sulfate 1.34\% $(\mathrm{w} / \mathrm{v})$, yeast extract $1 \%(\mathrm{w} / \mathrm{v})$, casein peptone $2 \%(\mathrm{w} / \mathrm{v})$, buffer potassium phosphate $(100 \mathrm{mM}) \mathrm{pH} 6.0$, biotin $4 \times 10^{-5} \%(\mathrm{w} / \mathrm{v})$, glycerol $1 \%(\mathrm{v} / \mathrm{v})$, casamino acids $2 \%$ $(\mathrm{w} / \mathrm{v}))$ and incubated at $30{ }^{\circ} \mathrm{C}$ and $250 \mathrm{rpm}$ for $16 \mathrm{~h}$.

\section{Preparation of $P$. pastoris inoculum in shaker (growth phase)}

For inoculum stage in a stirrer, was prepared BMGY medium through five solutions (A: $2 \mathrm{~g}$ Yeast Extract, $4 \mathrm{~g}$ peptone, dilute to $50 \mathrm{~mL}$ with deionized water; B: $20 \mathrm{~mL}$ buffer phosphate, $2 \mathrm{~g}$ glycerol; C: $2.68 \mathrm{~g}$ Yeast Nitrogen Base and dilute to $50 \mathrm{~mL}$ with deionized water, $2 \mathrm{~g}$ of ammonium sulfate and dilute to $40 \mathrm{~mL}$ with deionized water; D: $4 \mathrm{~g}$ casamino acids and dilute to $40 \mathrm{~mL}$ with deionized water; E: $400 \mathrm{~mL}$ of biotin) to $200 \mathrm{~mL}$ in a $500 \mathrm{~mL}$ Erlenmeyer flask and withdrew $10 \%$ (v/v) of the initial volume $(20 \mathrm{~mL})$ which was used to cultivate $200 \mathrm{~mL} P$. pastoris strain genetically modified and incubated at $30^{\circ} \mathrm{C}$ at $250 \mathrm{rpm}$ for $16 \mathrm{~h}$. Subsequently, the inoculum is transferred to $180 \mathrm{~mL}$ of BMGY medium and incubated at $30^{\circ} \mathrm{C}$ at $250 \mathrm{rpm}$ for $32 \mathrm{~h}$.

\section{Induction phase in a shaker}

After the growth phase $(32 \mathrm{~h})$ was added $1 \%(\mathrm{v} / \mathrm{v})$ and $3 \%(\mathrm{v} / \mathrm{v})$ methanol. To inhibit the production of protease was also added $1 \mathrm{mM}$ PMSF (phenylmethanesulfonylfluoride). Before addition of methanol, the temperature was adjusted to $10{ }^{\circ} \mathrm{C}$ and $30^{\circ} \mathrm{C}$. This induction phase was carried out after $24,48 \mathrm{~h}$ and $72 \mathrm{~h}$. The total culture time was $96 \mathrm{~h}$.

\section{Experimental design}

After $96 \mathrm{~h}$ each culture was centrifuged at $1957 \mathrm{x} \mathrm{g}$ for $30 \mathrm{~min}$ where aliquots of $2 \mathrm{~mL}$ were obtained for use it in subsequent trials. The samples for analysis corresponded to: $3 \mathrm{X}=3 \%(\mathrm{v} / \mathrm{v})$ methanol $-10{ }^{\circ} \mathrm{C} ; 4 \mathrm{X}=3 \%(\mathrm{v} / \mathrm{v})$ metha- 
nol $-30{ }^{\circ} \mathrm{C} ; 5 \mathrm{X}=1 \%(\mathrm{v} / \mathrm{v})$ methanol $-10{ }^{\circ} \mathrm{C}$. All the cultures were performed in triplicate.

\section{Quantification of proteins}

The cell lysate was performed for $30 \mathrm{~min}$ in ultrasonicator bath Elmasonic E 60 H (Elma, Singen, Germany). Quantification of proteins was performed through the Coomassie blue method (Bradford, 1976). The calibration curve was performed with BSA (stock $2 \mathrm{mg} / \mathrm{mL}$ ) to a standard concentration of $100 \mu \mathrm{g} / \mathrm{mL}$ and the dilution was made with distilled water, the absorbance measurement at $595 \mathrm{~nm}$ was performed in Spectrophotometer Optizen 3220 UV (Mecasys Co., Daejeon, Rep. of Korea) and its concentration was calculated according to the ratio initial volume and initial concentration $v s$. the volume and final concentration. According to the method of cell lysate was used 5 to $20 \mu \mathrm{L}$ of these cells within UV Macro $3.5 \mathrm{~mL}$ (Arquimed) was added distilled water to $100 \mu \mathrm{L}$ plus $1 \mathrm{~mL}$ of $1 \mathrm{X}$ Bradford, mixed and allowed to incubate for $5 \mathrm{~min}$ at room temperature and then be measured. The results were expressed as $\mathrm{mg}$ protein / $\mathrm{mL}$ of cells.

\section{SDS / PAGE and Western blot analysis}

To evaluate and correlate the expression levels of HIF-1 $\alpha$, and HSP-90, it measured the levels of all proteins to different growing conditions in shaker. The protein samples were separated by $7 \%$ SDS/PAGE for HIF-1 $\alpha$ and $10 \%$ SDS/PAGE HSP-90, then these were transferred to membrane Hybond-C (Amersham Pharmacia, Piscataway, NJ, USA) using a transfer cell Transfer-blot SD Semi-dry (Bio-Rad, Tokyo, Japan). The membranes were then blocked by incubation with 5\% skim milk in PBS, pH 7.2 for $1 \mathrm{~h}$ at room temperature (RT) under mild agitation. Subsequently, the membranes were incubated with rabbit anti(rat-HIF-1 $\alpha$ ) IgG (dilution 1:50) (Santa Cruz Biotechnology, Santa Cruz, CA, USA) and mouse anti-(rat-HSP-90) IgG (1:50 dilution) (Santa Cruz Biotechnology, Santa Cruz, CA, USA) for $16 \mathrm{~h}$ at $4{ }^{\circ} \mathrm{C}$. After the membranes were washed 5 times for 10 min with PBS pH 7.2, containing $0.1 \%$ Tween-20, a fourth wash was carried out only with PBS pH 7.2 to remove all traces of detergent, then were incubated with peroxidase-conjugated goat anti-(rabbit IgG) Ig (dilution 1:500) (Jackson Laboratories ImmuneResearch, PA, USA) and peroxidase-conjugated goat anti(mouse IgG) Ig (dilution 1:500) (Santa Cruz Biotechnology, Santa Cruz, CA, USA) for $2 \mathrm{~h}$. After being washed 5 times for 10 min with PBS $\mathrm{pH} 7.2$, containing $0.1 \%$ Tween-20 and once for 5 min with PBS pH 7.2 only, the peroxidase activity was detected by a chemiluminescent method using an ECL Plus kit (Amersham Pharmacia, Buckinghamshire, UK). The $\beta$-actin antibody was used as loading control in Western blot (Sigma) in dilution 1:50. The immunoblots were analyzed using ImageJ software (http://rsb.info.nih.gov/ij).

\section{Immunocytochemistry}

Cells were fixed in formalin $3.7 \%(\mathrm{v} / \mathrm{v})$ and permeabilized with cold methanol $\left(-20^{\circ} \mathrm{C}\right)$. Endogenous peroxidase was blocked with $0.3 \%(\mathrm{v} / \mathrm{v}) \mathrm{H}_{2} \mathrm{O}_{2}$ in dark for $30 \mathrm{~min}$ at RT. The cells were blocked with bovine serum albumin (BSA, Sigma-Aldrich) 5\% at RT for $15 \mathrm{~min}$ and washed for 5 min with PBS. They were then incubated with rabbit anti-(rat-HIF-1 $\alpha$ ) IgG (1:100 dilution) (Santa Cruz Biotechnology, Santa Cruz, CA, USA) and mouse anti-(ratHSP-90) IgG (1:100 dilution) (Santa Cruz Biotechnology, Santa Cruz, CA, USA) for $1 \mathrm{~h}$ at $37^{\circ} \mathrm{C}$ in a humid chamber. They were then incubated with peroxidase-conjugated goat anti-(rabbit IgG) IgG (dilution 1:1000) (Jackson Laboratories ImmuneResearch, PA, USA) and peroxidase-conjugated goat anti-(mouse IgG) IgG (dilution 1:1000) (St. Cruz Biotechnology, Santa Cruz, CA, USA) for $30 \mathrm{~min}$ at RT. The peroxidase activity was visualized using 1,3-diaminobenzidine (DAB) and were counterstained with hematoxylin. The slides were immersed in a series of alcohols, in increasing order $\left(70^{\circ}, 95^{\circ}\right.$ and $\left.100^{\circ}\right)$ for 5 min each one, allowed to soak for $10 \mathrm{~min}$ in xylol and finally made the final assemble end where the slides were observed under the microscope Optical BX43 (Olympus, Tokyo, Japan).

\section{Data analysis}

The results show that normal distribution was analyzed using One Way test - ANOVA followed by Tukey analysis. ANOVA analysis was performed to determine significant interaction between the expression of proteinsHIF- $1 \alpha$ and HSP-90 - and different culture conditions, because this could indicate a difference in expression of these molecules. The statistical significance level used was $\mathrm{p}<0.05$ for all tests. Results are presented as mean \pm standard deviation.

\section{Results}

\section{Expression level of HIF-1 $\alpha$ and HSP-90}

To compare the effect of different temperatures and concentrations of the inductor on cell density, we investigated the presence of proteins related to heat stress and hypoxia. The measurement of HIF-1 $\alpha$ was performed to determine the availability of oxygen to the cells. In $3 \%$ (v/v) methanol $-10{ }^{\circ} \mathrm{C}$ culture, HIF- $1 \alpha$ showed a higher expression than the cultures to $3 \%(\mathrm{v} / \mathrm{v})$ methanol $-30{ }^{\circ} \mathrm{C}$ and $1 \%(\mathrm{v} / \mathrm{v})$ methanol- $10{ }^{\circ} \mathrm{C}$ (Figure $\left.1 \mathrm{~A} ; \mathrm{p}<0.05\right)$ showing any relation between the factors analyzed with the hypoxic effect. HSP-90 in the three cultures is present to the same level (Figure 1B; $\mathrm{p}>0.05$ ).

\section{Presence in situ of heat shock and hypoxia proteins}

Since we determined the presence of heat stress and hypoxia proteins and are known to relate to each other, it 
was necessary to know the location of these within the yeast $P$. pastoris to relate to their function (Figure 2). HIF-1 $\alpha$ in the $3 \%(\mathrm{v} / \mathrm{v})$ methanol $-10{ }^{\circ} \mathrm{C}$ and $1 \%(\mathrm{v} / \mathrm{v})$ methanol -10 ${ }^{\circ} \mathrm{C}$ cultures is observed around the nucleus; while in the $3 \%$ (v/v) methanol $-30{ }^{\circ} \mathrm{C}$ culture is observed at the cytoplasm. Therefore, although none of the three cultures present difference between them in relation to their expression level, their location will indicate that in $\%(\mathrm{v} / \mathrm{v})$ methanol $-10{ }^{\circ} \mathrm{C}$ and $1 \%(\mathrm{v} / \mathrm{v})$ methanol $-10{ }^{\circ} \mathrm{C}$ cultures, HIF-1 $\alpha$ will be translocating from the cytoplasm into the nucleus, where it could induce transcription of other genes of importance for the development of yeast, but yet unknown the specific functionality and potential genes that could be related to this transcription factor. HSP-90, which is located in the three cultures dispersed throughout the cytoplasm, only some cells of $3 \%(\mathrm{v} / \mathrm{v})$ methanol $-30{ }^{\circ} \mathrm{C}$ culture show disseminated mark around the nucleus.

\section{Discussion}

The proper oxygenation of the culture is important for the metabolic functions of organisms are correctly accomplished. Paradoxically, it was recently shown that hypoxic conditions significantly increased the specific productivity of $P$. pastoris recombinant (Swartzlander et al., 2010), increased cell density, viability remained constant compared to control lines, but decreased the production of endogenous proteins (Baumann et al., 2010), indicating that yeast grown in cultures with limited oxygen availability significantly improve their characteristic to be a host with high capacity for purification of monoclonal antibodies. The results of HIF-1 $\alpha$ showed that the three cultures would be under limited conditions of oxygen (Figure 1A), but only in $3 \%(\mathrm{v} / \mathrm{v})$ methanol $-10{ }^{\circ} \mathrm{C}$ and $1 \%(\mathrm{v} / \mathrm{v})$ methanol $-10{ }^{\circ} \mathrm{C}$ cultures it would be translocating into the nucleus (Figure 2) to dimerize with ARNT (subunit $\beta$ of HIF-1), bind to DNA and activate the transcription of its target genes (Braliou et al., 2006). In contrast, despite the detection of $\mathrm{HIF}-1 \alpha$ in the $3 \%(\mathrm{v} / \mathrm{v})$ methanol $-30{ }^{\circ} \mathrm{C}$ culture, it was localized in the cytoplasm indicating that degradation would be constant due to the presence of oxygen in the culture, which should be considered that this may be related to the cell number because the agitation and aeration was constant and same for all three, so as $3 \%(\mathrm{v} / \mathrm{v})$ methanol $-10^{\circ} \mathrm{C}$ and $1 \%(\mathrm{v} / \mathrm{v})$ methanol $-10^{\circ} \mathrm{C}$ cultures were those who obtained higher cell density, especially the $1 \%(\mathrm{v} / \mathrm{v})$ methanol $-10^{\circ} \mathrm{C}$ culture. Therefore, by decreasing the amount of carbon source for growth to the same initial cell density and constant induction time for all these cultures, they must activate another system to survive as is the shift of a respiratory metabolism to a respiratory-fermentation (Baumann et al., 2010; Charoenrat et al., 2005), so that its main function using methanol as an inducer for the production of antibodies may be varying a function of production of ethanol which acts as a repressor generating a negative feedback in the
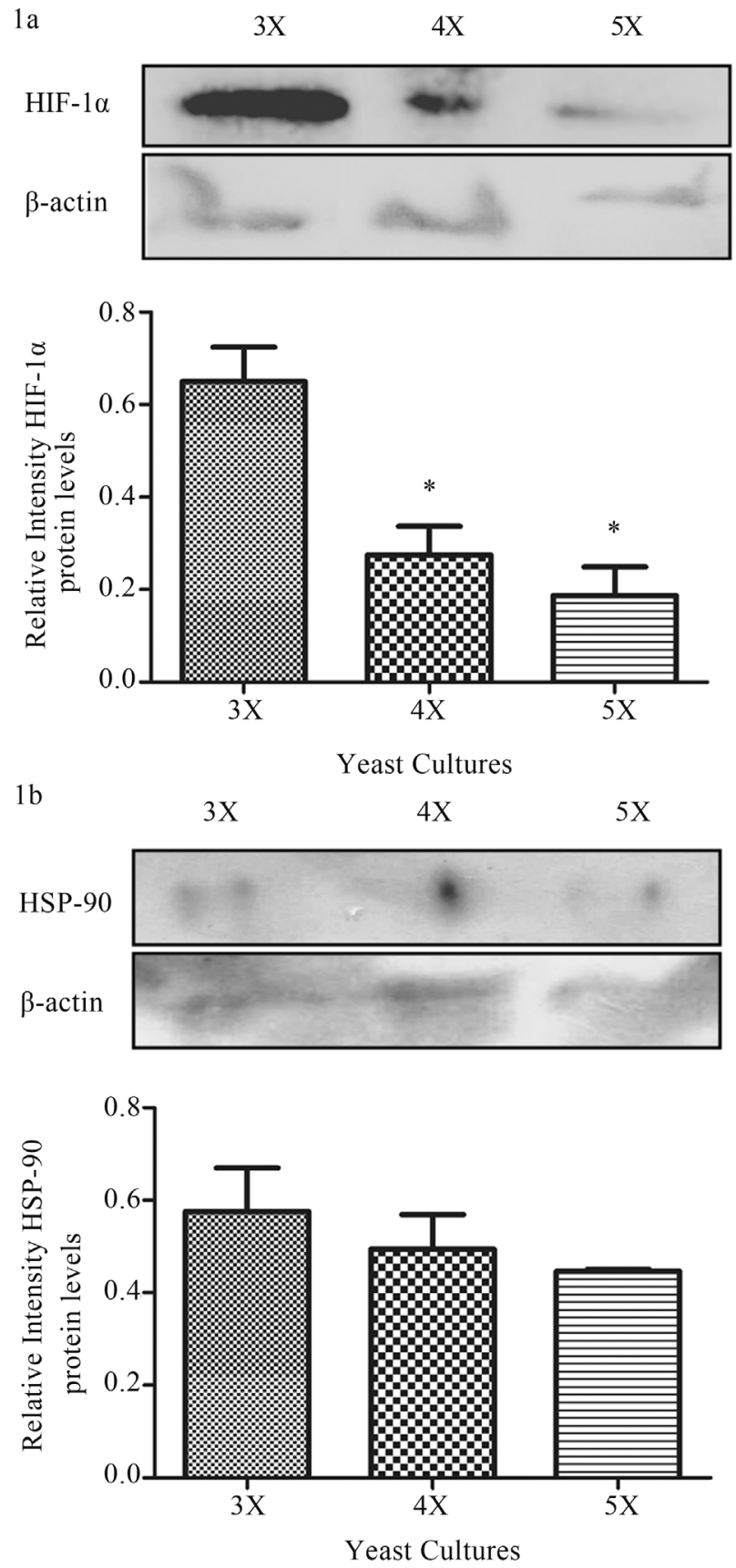

Figure 1 - Protein expression level of heat stress and hypoxia proteins. Western blotting and band intensity obtained from samples with different conditions of temperature and concentration of methanol were analyzed where: A) HIF-1 $\alpha$ and B) HSP-90. The bars indicate mean \pm standard deviation of $n=3$. Statistical analysis: ANOVA one-way (one-way) followed by Tukey analysis. There was no significant difference between either group $(\mathrm{o}>0.05) .3 \mathrm{X}=3 \%(\mathrm{v} / \mathrm{v})$ Methanol $-10{ }^{\circ} \mathrm{C}, 4 \mathrm{X}=3 \%(\mathrm{v} / \mathrm{v})$ Methanol $-30{ }^{\circ} \mathrm{C}, 5 \mathrm{X}=1 \%(\mathrm{v} / \mathrm{v})$ Methanol $-10{ }^{\circ} \mathrm{C}$.

culture or the production of lactate to relate directly with the high cell density culture obtained in $1 \%(\mathrm{v} / \mathrm{v})$ methanol $-10{ }^{\circ} \mathrm{C}$ culture generating the oxygen consumption rate is greater therefore be exhausted in a shorter time further enhancement of anaerobic fermentation pathway. 


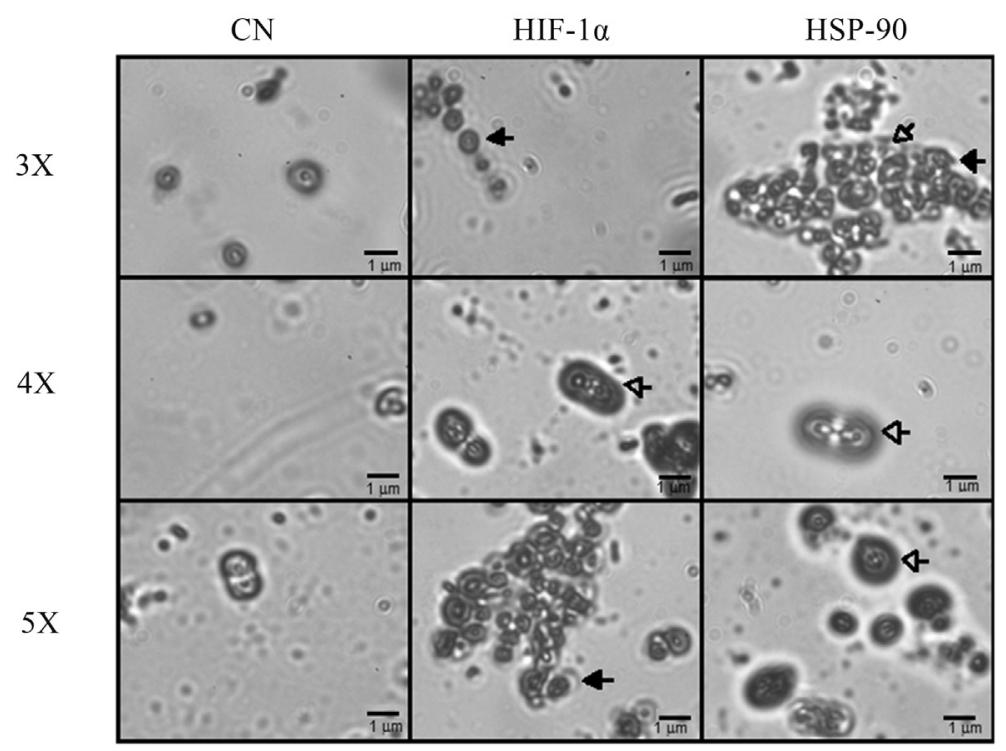

Figure 2 - Presence in situ of heat shock and hypoxia proteins. Immunolocalization of HIF-1 $\alpha$ protein and HSP-90 in yeast cells $P$. pastoris under conditions of temperature and concentration of methanol different. White-tipped arrow indicate citoplasmatic location, and black-tipped arrow indicate nuclear location. $3 \mathrm{X}=3 \%(\mathrm{v} / \mathrm{v})$ Methanol $-10{ }^{\circ} \mathrm{C}, 4 \mathrm{X}=3 \%(\mathrm{v} / \mathrm{v})$ Methanol $-30{ }^{\circ} \mathrm{C}, 5 \mathrm{X}=1 \%(\mathrm{v} / \mathrm{v})$ Methanol $-10{ }^{\circ} \mathrm{C}$.

We must also consider that homeostasis of HIF-1 $\alpha$ is also regulated by other factors, not only oxygen, such as thermal stress would be of great importance when you consider that could affect the production of monoclonal antibodies, because in recent years have shown that the correct folding protein and secretion are highly interrelated with environmental stresses (Charoenrat et al., 2005). In almost all living systems, upshifts in temperature cause heat stress response that leads to a strong induction of a conserved group of proteins called heat shock proteins (HSPs) (Guerra et al., 2005), yet it has been found a decrease in protein folding at low temperatures and, thus, a possible correlation with the beneficial effect on protein secretion (Dragosits et al., 2010). In this study, we observed that the response is different to that reported by other authors, where the $3 \%$ $(\mathrm{v} / \mathrm{v})$ methanol $-30{ }^{\circ} \mathrm{C}$ culture in comparison with $3 \%(\mathrm{v} / \mathrm{v})$ methanol $-10{ }^{\circ} \mathrm{C}$ and $1 \%(\mathrm{v} / \mathrm{v})$ methanol $-10{ }^{\circ} \mathrm{C}$ cultures is the one with a lower concentration of total protein, where the heat stress generated by the $30{ }^{\circ} \mathrm{C}$ would act beneficially on the production of antibodies to activate the chaperone may be protecting peptides to acquire the proper conformation of a mature protein. We did find HSP-90 (cytoplasm and nucleus) (Figure 2), relating to the stabilization of HIF- $1 \alpha$ to activate the transcription factor function, perhaps concerning with target genes of the respirative-fermentative metabolism and/or cell proliferation.

\section{Conclusion}

According to this information, high temperatures and high concentrations of inductor would act positively on the production of monoclonal antibodies, while a condition of hypoxia would decrease the production but would increase the cell number, conversely to what was initially believed that a higher cell density matched with a high production of monoclonal antibodies. Because of there is little information about $P$. pastoris is a need for more research to evaluate the influence of oxidative stress on the physiology, metabolism and cell communication mechanisms of this expression system, which would gain more knowledge about the functioning of the yeast and then design and strategies to improve the production of heterologous proteins from $P$. pastoris recombinant.

\section{Acknowledgments}

The authors are sincerely thankful for support provided by CONICYT doctoral fellowship to A.Z. and C.F., FAPESP (Fundação de Amparo à Pesquisa do Estado de São Paulo, Brasil, Processo Número: 2012/50210-9), International Cooperation Program of Universidad de La Frontera DI12-4001 and DIUFRO grant DI12-2007

\section{Competing Financial Interests}

The authors declare no competing financial interests.

\section{References}

Baumann K, Carnicer M, Dragosits M, Graf AB, Stadlmann J, Jouhten P, Maaheimo H, Gasser B, Albiol J, Mattanovich D, Ferrer P (2010) A multi-level study of recombinant Pichia pastoris in different oxygen conditions. BMC Syst Biol 4:141.

Bradford MM. (1976) A rapid and sensitive method for the quantitation of microgram quantities of protein utilizing the principle of protein-dye binding. Anal Biochem 72:248-254.

Braliou GG, Venieris E, Kalousi A, Simos G (2006) Reconstitution of human hypoxia inducible factor HIF-1 in yeast: a 
simple in vivo system to identify and characterize HIF1alpha effectors. Biochem Biophys Res Commun 346:1289-1296.

Buchner J (1999) Hsp90 \& Co. - a holding for folding. Trends Biochem Sci 24:136-141.

Cereghino JL, Cregg JM (2000) Heterologous protein expression in methylotrophic yeast Pichia pastoris. FEMS Microbiology Reviews 24:45-66.

Dragosits M, Stadlmann J, Graf A, Gasser B, Maurer M, Sauer M, Kreil DP, Altmann F, Mattanovich D (2010) The response to unfolded protein is involved in osmotolerance of Pichia pastoris. BMC Genomics 11:207.

Charoenrat T, Ketudat-Cairns M, Stendahl-Andersen H, Jahic M, Enfors SO (2005) Oxygen-limited fed-batch process: an alternative control for Pichia pastoris recombinant protein processes. Bioprocess Biosyst Eng 27:399-406.

Ficker E, Dennis AT, Wang L, Brown AM (2003) Role of the cytosolic chaperones Hsp70 and Hsp90 in maturation of the cardiac potassium channel HERG. Circ Res 92:87-100.

Fischer R, Drossard J, Emans N, Commandeur U, Hellwig S (1999) Towards molecular farming in the future: Pichia pastoris-based production of single-chain antibody fragments. Biotechnol Appl Biochem 30:117-120.

Fukuda A, Osawa T, Oda H, Tanaka T, Toyokuni S, Uchida K (1996) Oxidative stress response in iron-induced acute nephrotoxicity: enhanced expression of heat shock protein 90 . Biochem Biophys Res Commun 219:76-81.

Gogate SS, Fujita N, Skubutyte R, Shapiro IM, Risbud MV (2012) Tonicity enhancer binding protein (TonEBP) and hypoxia-inducible factor (HIF) coordinate heat shock protein 70 (Hsp70) expression in hypoxic nucleus pulposus cells: role of Hsp70 in HIF-1 $\alpha$ degradation. J Bone Miner Res 27:1106-1117.

Guerra E, Chye PP, Berardi E, Piper PW (2005) Hypoxia abolishes transience of the heat-shock response in the methylotrophic yeast Hansenula polymorpha. Microbiology 151:805-811.
Isaacs JS, Jung YJ, Mimnaugh EG, Martinez A, Cuttitta F, Neckers LM (2002) Hsp90 regulates a von Hippel Lindauindependent hypoxia-inducible factor-1a-degradative pathway. J. Biol. Chem 277:29936-29944.

Mabjeesh NJ, Post DE, Willard MT, Kaur B, Van Meir EG, Simons JW, Zhong H (2002) Geldanamycin induces degradation of hypoxia-inducible factor 1a protein via the proteosome pathway in prostate cancer cells. Cancer Res 62:2478-2482.

Mattanovich D, Gasser B, Hohenblum H, Sauer M (2004) Stress in recombinant protein producing yeasts. J Biotechnol 113:121-135.

Mayer MP, Bukau B (1999) Molecular chaperones: the busy life of Hsp90. Curr Biol 9:R322-325.

Ni Z, Zhou X, Sun X, Wang Y,Zhang Y (2008) Decrease of hirudin degradation by deleting the KEX1 gene in recombinant Pichia pastoris. Yeast 25:1-8.

Semenza GL (2001) HIF-1 and mechanisms of hypoxia sensing. Curr Opin Cell Biol 13:167-171.

Solà A, Jouhten P, Maaheimo H, Sánchez-Ferrando F, Szyperski T, Ferrer P (2007) Metabolic flux profiling of Pichia pastoris grown on glycerol/methanol mixtures in chemostat cultures at low and high dilution rates. Microbiology 153:281-290.

Swartzlander DB, Griffiths LM, Lee J, Degtyareva NP, Doetsch PW, Corbett AH (2010) Regulation of base excision repair: Ntg1 nuclear and mitochondrial dynamic localization in response to genotoxic stress. Nucleic Acids Res 38:39633974.

Verbelen PJ, Depraetere SA, Winderickx J, Delvaux FR, Delvaux F (2009) The influence of yeast oxygenation prior to brewery fermentation on yeast metabolism and the oxidative stress response. FEMS Yeast Res 9:226-239.

Wagstaff MJ, Collaço-Moraes Y, Aspey BS, Coffin RS, Harrison MJ, Latchman DS, de Belleroche JS (1996) Focal cerebral ischaemia increases the levels of several classes of heat shock proteins and their corresponding mRNAs. Brain Res Mol Brain Res 42:236-244.

All the content of the journal, except where otherwise noted, is licensed under a Creative Commons License CC BY-NC. 